\title{
Interactive Space in the Context of Improving School Life Patterns
}

\author{
Anastasiya A. Smirnaia ${ }^{a, b}$ \\ and Ludmila A. Kozlova ${ }^{\mathrm{b} *}$ \\ ${ }^{a}$ Reshetnev Siberian State University \\ of Science and Technology \\ 82 Mira, Krasnoyarsk, 660049, Russia \\ ${ }^{b}$ Krasnoyarsk State Institute of Arts \\ 22 Lenin Str., Krasnoyarsk, 660049, Russia
}

Received 20.01.2017, received in revised form 31.07.2017, accepted 10.07.2017

This article reveals the idea of an interactive space in the context of improving school life patterns. Creation of an interactive educational space as a condition for improving the interaction of an adult and a child in the structure of the school life assumes a step-by-step implementation of this condition: the first stage is retrospective; the second stage is the creation of an eventual environment; the third stage is maintaining the interactive educational space in an effective mode. In this regard, as the main indicators of the functioning of the interactive educational space in the school are mutual information sharing, coordination, joint activities, mutual assistance, the use of information about the child for their benefit, the rules of life in school based on tolerance principles.

Keywords: interactive space, patterns, school life patterns, interaction of a child and an adult.

DOI: $10.17516 / 1997-1370-0132$.

Research area: pedagogical sciences.

Historically developed ideas about the school life patterns expressed in terms of "school spirit" and "school life" received new development in modern pedagogy, which was expressed in specifying the concept of "school life" and its characteristics.

Considering culture as a set of traditions and norms, prejudices and expectations that determine the actions of employees in conditions that require elaboration of their own attitude and action, I.D. Frumin points out that such an interpretation of culture is close to the idea of the pattern of life.
"Under the school life pattern, we first understand the prevailing system of educational and extracurricular relations, which is viewed not as a system of personal relationships, but as a set of conditions in which the behaviour and activities of pupils and teachers take place" (Frumin, 1999: 114). To understand and analyze the way of life, I.D. Frumin considers it necessary to observe free, not directly regulated activities of children and teachers, their conversations at breaks, their activities in conditions of free choice, and their life in out-of-school settings - a camp, for

(C) Siberian Federal University. All rights reserved

* Corresponding author E-mail address: nastenasm@yandex.ru; gimn6-2007@yandex.ru 
example. Comparison of this type of behaviour and activities with regulated and standardized behaviour in the conditions, for example, of a lesson, gives grounds for distinguishing such school norms that transform behaviour.

Working in the context of V.V. Ignatova's concept, and following the pedagogical meaning of the definition of the concept of "pedagogical provision", which we understand as "the combination of factors and conditions for their deployment through special pedagogical forms, methods and techniques (technologies taking into account the effectiveness criteria for their implementation)" (Ignatova, 2000: 113), we connect pedagogical support with a combination of pedagogical circumstances and actions on which the improvement of school life patterns depends. In this article, we pay attention to one of the conditions for improving the interaction of an adult and a child in the structure of the school life: the creation of an interactive educational space. This is due to the fact that the interaction between an adult and a child is one of the leading components in the structure of the school life (which is given by definition) and must be actively supported in the educational process of the modern school through various interactive strategies, methods, techniques, methods and means.

Theoretically, our research is based on fundamental ideas about personality-oriented education (Bondarevskaia, Kul'nevich, 1999); about the educational space as a space for joint life activity (Valeeva, 2014: 58-62; Fel'dshtein, 2002); about the formation of school life patterns (Karakovskii, 1992, Frumin, 1999) and interactive processes in education (Rudenskii, 2000; Slastenin, 2000); about the development of social practices (Vetrov, Konishevskii, 2014: 91-97).

Proceeding from the abovementioned concepts, the unit (subject) of the educational space is a pedagogical event as the moment of interaction with the child, co-being designed by the teacher. We share the point of view of those scientists who connect the etymology of the term "interactive" with the notion "interaction", as a direct dialogue, co-being, value-semantic interaction as a part of socialization and role behaviour of the person: "inter" (Latin $<$ inter between) and (Latin < actio - action (mission) associated with speaking, addressing someone, semantic interpretation undertaken to achieve some goal) (Slobodchikov, Isaev, 2000: 28-29).

The Concept of the Federal Targeted Development Programme for 2011-2015 primarily focuses on the modern model of successful adaptation and socialization of children: the creation of an innovative educational model; development of a safe lifestyle culture; development of a system of psychological and pedagogical support for pupils. Creation of an interactive educational space in the context of improving the way of school life, from our point of view, is one of the mechanisms for reaching the objectives of the modern (innovative) school, which determine the strategy for the development of Russian education for the future. Designing and organizing the pedagogical events of joint activities and communication of an adult and a child as interconnected and interdependent, supporting the chosen level of their dynamics, targeted and interactive orientation, the school creates an interactive educational space (the interactive sphere between an adult and a child the joint being of the educator and educated), thus contributing to the improvement of school life patterns.

The key strategic moment in creating such an educational space (interpersonal, event space of interaction) was the idea of social interaction. Social interaction is understood by us as a process in which individuals and groups, in the course of communication, influence on other individuals and groups through their behaviour provoking 
reciprocal reactions, in fact, this is the process of interdependent influence of individuals, groups, social systems, societies on each other (Korotaeva, 2000).

In accordance with the ideas of social interaction, we have outlined the following principles of organizing such a space: ensuring a stable interpersonal connection in the process of joint activities and communication through the establishment of cooperation, when it is required to find interactive ways of coordinating intentions, positions, actions; achieving a similar vision of the pedagogical situation in interaction with pupils; allocation of one's personal position (I-space) in a given space, that is, the definition of one's attitude to other participants of the educational process, to the events of school life, to oneself personally.

Against this background, the joint activity of the teacher, parents, and pupil resulted in: a new interactive content; expansion of the spatial boundaries of the educational process contributing to their mutual spiritual development and enrichment; improvement of the way of life of the entire school.

Basing on the research of V.N. Kunitsyna (Kunitsina et al., 2002: 112), we identified the basic interactive mechanisms that provide the creation of an interactive educational space. This is mutual understanding and coordination, which all together constituted the process in which participants of the educational process acquired that very subject of co-being, understood the meaning of interaction, built relationships and showed themselves. This led to the search for means and ways of creating a common semantic field of participants of interaction, combining their interests, developing a similar vision of tasks in a specific situation. In the choice of these means, we are guided by the fact that they activate the cognitive, need-motivation, activity-related spheres of the adult's and child's personality.
Creation of the school interactive educational space is carried out step by step, where the basic interactive mechanisms that ensure the creation of an interactive educational space are mutual understanding and coordination, which together form a process in which participants of the educational process identify the meaning of interaction, build relationships and show themselves. These mechanisms activate the cognitive, need-motivation, activity-related spheres of the adult's and child's personality.

The first stage is retrospective and is connected with the reference to the past experience of the school, a review of past events, which are subject to evaluation and an occasion for reflection and reason for life conclusions. The second stage is the creation of an eventual environment. It is associated with the actualization of the totality of events that serve as the basis for involving schoolchildren, teachers and parents in what is happening in the school and "building up" social interaction. The third stage is the maintenance of productive interaction focused on self-realization of an adult and a child in the interactive field, the ability to work as a team, "everybody's success", support for corporativity (Kozlova, 2003: 133). Let us dwell on the content of the activity that characterizes each of these stages.

The retrospective stage is connected with the study of the past experience of the school. At the same time, attention is paid to the peculiarities of interaction between the participants of the educational process. Therefore, different forms of interaction are distinguished: cooperation, unilateral acceptance, evasion from interaction, unilateral opposition, confrontation, compromise interaction. Interrogation of parents, teachers and pupils has shown that all these strategies of interpersonal interaction are typical for the school. In the process of analyzing the events of school life, the following facts were revealed: "destruction of the educational system", 
"declaration of the ideas of the pedagogy of cooperation", "presence of signs of an ultimatum, unified, utilitarian, utopian way of life and the absence of signs of a universal way of school life", "alienation of schoolchildren and parents from school", "low motivation of teachers to improve their skills", "lack of children's selfgovernment", "low public activity", "ignoring the ethno-cultural needs of the participants of the educational process", etc.

The review of the events of school life, which serve as the subject of evaluation and reason for reflection, allowed us to formulate the conclusions that served as the basis for further activities to create an interactive educational space.

Firstly, in the process of improving school life patterns, the organization of interaction between an adult and a child on the basis of social and pedagogical values as a unity of spiritual, creative, organizational and praxeological guides for pupils (mutual respect, spiritual generosity, co-creation, emotional openness, free selfdetermination) is considered to be one of the the priority objectives (Smirnaia, 2008: 54).

Secondly, in order to prevent the emergence of negative events in school life, to overcome the abovementioned facts, it is necessary to carry out activities to orient adults and children to co-organize their activities in order to meet educational needs.

The first stage in the creation of the school interactive educational space determined the content of its second stage. As noted above, the second stage is the stage of creating an event environment. Firstly, the events that serve as the basis for involving pupils, teachers and parents to the actual moments of the school are kept up-todate here, and secondly, the strategy is chosen and implemented that is aimed at "building up" social interaction. At the second stage, the strategy of harmonization of relations between adults and children is consistently implemented through the development of children's self-government in the school; through the goal of modern education as a factor for achieving harmony, productive interaction between the man and the world, human groups and communities.

The implementation of this stage begins with the creation of children's self-government in the school. First of all, it is necessary to define the principles as guiding ideas, the rules of its formation. The principles are selected basing on "free preference". Schoolchildren, representatives of various age groups and classes discuss the "set" of principles that they have been provided with and identify those that correspond to their vision of self-goverment in school. Some principles are adjusted, supplemented by an expert group, which includes teachers and parents. As a result of the work, the following principles have been outlined.

The principle of integrity: a) an organizer for each activity, a governing body for each subsystem, each direction of work; b) effective rights and obligations for each body; c) hierarchy of management: subordination, subordination in combination with the rights and freedom of choice of pupils. The principle of dominance: members of self-government bodies tend to possess more highly intellectual and spiritually creative features. The principles of continuity and adaptability: a) interrelationship and transfer of experience is expected; b) existence of standards (plans, instructions, instructions); c) constant training of employees and acquisition of experience in the theory and practice of management. The principle of expediency and optimality: all actions of self-government bodies are aimed at the implementation of the abovementioned goals and objectives with the least effort and the best results, due to responsibility and creative search. The principle of direct communication and feedback: 
“transparency", publicity, truthfulness, reliability and timeliness of information are obligatory. The principle of nonviolence: full development and functioning of an individual, maintenance of their self-development and self-realization, denial of various forms of coercion. The principle of harmonization of communication: concern for the safety of a person as a person, as a subject of interaction. The principle of immediate coordination: obtaining a common opinion, taking an effective decision regarding organizational and managerial actions in all spheres of the life activity of the school.

These principles served as the basis for developing the main ideas of children's selfgovernment in school, for which an initiative group was elected, which included the administration, teachers, members of the parent committee and pupils. To organize self-government, independent and initiative judgments and actions of children were ensured by the whole way of school life. The "implementation" of self-government is a dynamic, continuously evolving process that represents the movement of the team from the control of teachers to self-government, the gradual transfer of management links "into the hands" of pupils themselves.

On the school scale, a parliament is being created. The Parliament members are elected by universal suffrage taking into account the development of specific activities (a committee is created for activities that need to be developed in the team); features of the model of the civil society (within the school it was supposed to "play" the model of civil society - the elected parliament); free expression of will and initiative of schoolchildren. The granting of rights, the determination of the duties of members of parliament are accompanied by systematic training.

To ensure the unity of action of all government bodies in the school, the School
Council is formed, which includes the administration, teachers, pupils and parents. The School Council determines and clarifies the structure of self-government in the school, the functions, the sphere of activity of the selfgoverning bodies, ensures the coordination of the work of all bodies in accordance with a common plan, in the implementation of which each body performs its role, interacting with others, but not duplicating them. Children's self-government covers all age groups (junior, middle, senior chambers) and is a combination of one-age teams and committees of the Parliament. The elective company takes place annually with the expectation that the re-elected pupils could help the new staff.

The organization of children's selfgovernment in the school is connected with the creation of conditions under which pupils can manifest spiritual and creative features, independence, responsibility, join active useful activities, enter into moral collective relations. Pedagogical assistance from adult participants in school life supposes involvement of pupils into organizational activities; teaching pupils organizational skills; development of their activity, initiatives, independence, etc.

The creation of children's self-government is regarded by us as one of the most important events of modern school life. This strategy is seen through the implementation of cooperation, mutual enrichment, developoment of constructive relations, coherence, combination of directions, sides and trends of the pedagogical process.

Thus, the second stage of the creation of the school interactive educational space assumes not only the organization of children's selfgovernment in the school, but also the realization of the mission of modern (innovative) education as a factor in achieving harmony, productive interaction between the man and the world, human groups and communities. 
The next step in the creation of the interactive educational space of the school is to support its functioning in an effective mode through productive interaction focused on self-realization of the adult and the child in the interactive field, the ability to work as a team, "everybody's success", support for corporativity.

Under the effective mode of functioning of the interactive educational space, we mean its effective impact on the realization of educational goals related to the productive interaction of adults and children in the system of improving school life patterns, its universal features. This stage is connected with the improvement of the interactive educational space of the school basing on the development of the concept of the educational system and the allocation of mini-blocks of productive interaction in its content; actualization of creative potential of schoolchildren and teachers on the basis of project activities; activation of selfmanagement activity of schoolchildren; expansion and strengthening of interaction with the family. In fact, this stage has no specific time limits and can exist for a long time.

Due to the reasons of limited volume of the article, we are not able to describe the miniblocks of the concept that were realized in the process of the modern school life and we will stop on one of them as an example. Thus, in this concept a new look at the personality of an adult and a child is presented and highlighted: the ability to reflection, self-estimation; the ability to understand, sympathize; inclusion in the present, the ability to receive joy from school; ability to self-organization; the ability to spiritually creative activity; the need for selfrealization, self-respect. As a source and means of study, the knowledge of a child and an adult is the observation of them, their joint participation in school life.

The procedural moments for creating an interactive educational space are constantly monitored and discussed with teachers and schoolchildren during special workshops, where they discuss the specifics of their interaction, interaction with their parents. These workshops provide information on positive and negative educational impacts; forms of encouragement of schoolchildren in the educational process; features of features, manners of behaviour and communication of the teacher, personal characteristics and professional qualities, characterizing their individual style; abilities that the teacher must possess, etc. Moreover, the "ideal model" of the teacher, who feels at home with interactive communication techniques, is discussed.

Stressing the significance of the workshops, it can be noted that they are prolonged in time and differ in the form of their organization: workshops-debates, self-knowledge workshops, "technology" workshops during which various instrumental techniques, principles, mechanisms that promote understanding and coordination in the process of joint activities and communication are analyzed.

As noted above, this stage is connected with updating of the creative potential of teachers and schoolchildren on the basis of their joint project activities. A special place in the school can be occupied by project activities in the field of computer science, support and activation of which is considered by us as a means of expanding the school interactive educational space. Already starting from the elementary school, in the framework of the propaedeutic course, pupils have various projects, such as designing computer fairy tales, creating crosswords, cartoons, teaching and developing games, etc. In the basic course of computer science, studying of individual elements of computer technology occurs with the application of the design method. In senior grades, where the content of education has profile and in-depth orientation and is a 
system of various courses, the educational process is organized in the form of development and implementation of creative projects by each student or group.

The purposeful work on the organization of pupils' project activities resulted in the creative cooperation between the teacher of computer science, the pupil and the subject teacher. Parallel to this activity, school teachers can develop and protect projects related to the organization of educational work in classes and school.

Working with parents is not forced, nonviolent, which is an indicator of partnership. This is evidenced by a survey of parents of graduating students, who showed that more than $90 \%$ of them note satisfaction with the cooperation with the school and the quality of education of their children. In addition, in the process of expert's assessment of the activity of the gymnasium, parents are repeatedly questioned about their satisfaction with their interaction with the school.

Thus, the creation of an interactive educational space for a gymnasium in the context of improving its way of life is a long process that involves improving both its substantive, organizational and managerial aspects. This process is carried out step by step: from the retrospective stage, to the stage of creation of the event environment and to the stage of maintaining productive interaction.
The retrospective stage involves studying the past experience of the school, describing the real situation and highlighting the value orientations (pedagogical event) of creating an interactive educational space for a modern school.

Thestage of creating an eventual environment is connected with the implementation of the strategy of social interaction, as a strategy of involvement into what is happening in the school, harmonization of the relations between adults and children through the creation and development of schoolchildren's selfmanagement and the expansion of international relations of the gymnasium in accordance with profile development.

The stage of supporting the functioning of the school interactive educational space in an effective mode is realized through the organization of productive interaction between an adult and a child, creating conditions for their self-realization (joint project activity, supporting the self-government activity of schoolchildren and expanding interaction with the family).

The main indicators of the functioning of the interactive educational space are: mutual information sharing, coordination, joint activities, mutual assistance, use of information about the child for their benefit, rules of life in the school based on the principles of tolerance.

Table 1. Summarized results of interviews with teachers, parents and pupils regarding the indicators of the interactive educational space in $\%$

\begin{tabular}{|c|l|c|c|c|c|}
\hline No. & \multicolumn{1}{|c|}{ Features of the interactive educational space } & $\begin{array}{c}\text { Teachers } \\
(60 \text { people })\end{array}$ & $\begin{array}{c}\text { Parents } \\
(150 \text { people })\end{array}$ & $\begin{array}{c}\text { Pupils } \\
(450 \text { people })\end{array}$ & $\begin{array}{c}\text { Average } \\
\text { value }\end{array}$ \\
\hline 1. & Mutual information sharing & $75 \%$ & $80 \%$ & $88 \%$ & $81.0 \%$ \\
\hline 2. & Coordination & $60 \%$ & $72 \%$ & $84 \%$ & $72.0 \%$ \\
\hline 3. & Joint activities & $96 \%$ & $64 \%$ & $93 \%$ & $84.3 \%$ \\
\hline 4. & Mutual assistance & $85 \%$ & $60 \%$ & $86 \%$ & $77.0 \%$ \\
\hline 5. & Use of information about the child for their benefit & $91 \%$ & $86 \%$ & $82 \%$ & $86.3 \%$ \\
\hline 6. & $\begin{array}{l}\text { Rules of life in the school based on the principles of } \\
\text { tolerance }\end{array}$ & $90 \%$ & $76 \%$ & $80 \%$ & $82.0 \%$ \\
\hline
\end{tabular}


To determine the presence of these indicators in the life of the school, a survey was conducted, the results of which are presented in Table 1.

In general, the analysis of the survey results shows that the majority of interviewed respondents notice features of the interactive educational space in the school. Schoolchildren (pupils of 6-11 grades were interviewed), parents and teachers noted the use of information about the child for their benefit. This feature ranked first in the list. The second place was joint activity and the third rules of life in the school based on the principles of tolerance. All other features also have high values. Thus, the creation of the interactive educational space serves as a condition for improving the interaction of the adult and the child in the structure of the school life.

\section{References}

Bondarevskaia, E.V., Kul'nevich, S.V. (1999). Pedagogika: lichnost'v gumanisticheskikh teoriiakh i sistemakh vospitaniia [Pedagogy: personality in humanistic theories and systems of education]. Rostov-na-Donu, Uchitel‘ Publ. 560 p.

Fel'dshtein, D.I. (2002). Vozrastnaia $i$ pedagogicheskaiia psikhologiia [Age-related and pedagogical psychology]. Moscow, MPSI Publ.; Voronezh, Modek Publ. 432 p.

Frumin, I.D. (1999). Tainy shkoly: zametki o kontekstakh: monografiia [Secrets of school: notes about the contexts: monograph]. Krasnoiarsk, KGU Publ. 256 p.

Ignatova, V.V. (2000). Pedagogicheskie factory dukhovno-tvorcheskogo stanovleniia lichnosti v protsesse sotsializatsii: dissertatsiia doktora pedagogicheskikh nauk [Pedagogical factors of spiritual and creative development of the personality in the process of socialization: dissertation of the doctor of pedagogical sciences]. Krasnoiarsk, SibGTU Publ. 365 p.

Karakovskii, V.A. (1992). Vospittel 'naia Sistema shkoly: pedagogicheskie idei i opyt formirovaniia [The educational system of the school: pedagogical ideas and experience of formation]. Moscow, Novaia shkola Publ. 128 p.

Kozlova, L.A. (2003). Obnovlenie uklada shkol'noi zhizni: dissertatsiia kandidata pedagogicheskikh nauk [Updating the way of school life: dissertation of the candidate of pedagogical sciences]. Krasnoiarsk. 240 p.

Kontseptsiia Federal'noi tselevoi programmy razvitiia obrazovaniia na 2011-2015 gody [The concept of the Federal target program of development of education for 2011-2015] Available at: http:// www.garant.ru/products/ipo/prime/doc/55070647/ (accessed 13 November 2015).

Korotaeva, E.V. (2000). Direktor-uchitel'-uchenik: puti vzaimodeistviia [Director-teacherstudent: Ways of interaction]. Moscow, Sentiabr' Publ. 144 p.

Kunitsina, V.N., Kazarinova, N.V., Pogol'sha, V.M. (2002). Mezhlichnostnoe obshchenie [Interpersonal communication]. St. Peterburg, Piter Publ. 544 p.

Rudenskii, E.V. (2000). Eksperimental'no-psikhologicheskie osnovy sotsial'no-pedagogicheskoi viktimologii [Experimentally-psychological basis of social and pedagogical victimology]. Novosibirsk, NGPU Publ. 143 p.

Slastenin, V.A., Chizhakova, G.I. (2003). Vvedenie v pedagogicheskuiu aksiologiiu [Introduction to the pedagogical axiology]. Moskow, Akademiia Publ. $187 \mathrm{p}$.

Slobodchikov, V.I., Isaev, E.I. (2000). Osnovy psikhologicheskoi antropologii. Psikhologiia razvitiia cheloveka. Razvitie sub"ektivnoi real'nostiv ontogeneze [Fundamentals of psychological 
anthropology. Psychology of human development: The development of subjective reality in ontogenesis]. Moscow, Shkol'naia Pressa Publ. 416 p.

Smirnaia, A.A., Ignatova, V.V. (2008). Priobshchenie budushchego spetsiolista sotsial'noi raboty $k$ sotsial'no-pedagogicheskim tsennostiam: dissertatsiia kandidata pedagogicheskikh nauk [Familiarizing of the future specialist of social work to the socially-pedagogical values: dissertation of the candidate of pedagogical sciences]. Krasnoiarsk. 279 p.

Valeeva, E.V. (2014). Kontinual'nost' kak metodologicheskii printsip issledovaniia sovremennogo obrazovatel'nogo prostranstva [The continuity principle as methodological principle of research of modern educational space]. Voprosy kul'turologii [The culturology issues], (3), 58-62.

Vetrov, S.A., Konishevskii, D.V. (2014). K voprosu ob aktual'nosti sotsial'nykh praktik [To the question about actuality of social practices]. Voprosy kul 'turologii [The culturology issues], (3), 91-97.

\title{
Интерактивное пространство \\ в контексте совершенствования уклада \\ школьной жизни
}

\author{
А.А. Смирная ${ }^{\mathbf{a}, \mathbf{0}}$, Л.А. Козлова ${ }^{6}$

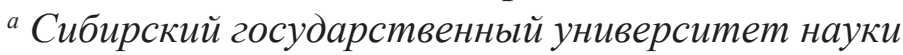 \\ и технологий имени академика М. Ф. Решетнева \\ Россия, 660049, Красноярск, пр. Мира, 82 \\ ${ }^{\sigma}$ Красноярский государственный институт искусств \\ Россия, 660049, Красноярск, ул. Ленина, 22
}

\begin{abstract}
В данной статье раскрывается содержание интерактивного пространства в контексте совершенствования уклада школьной жизни. Создание интерактивного воспитательного пространства как условие совершенствования взаимодействия взрослого и ребенка в структуре уклада школьной жизни предполагает поступенчатую реализацию данного условия: первая ступень - ретроспективная, вторая - ступень создания событийного окружения, третья ступень - поддерживание функиионирования интерактивного воспитательного пространства в эффективном режиме. В этой связи в качестве основных признаков функционирования интерактивного воспитательного пространства в школе выступают взаимное информирование, согласование, совместная деятельность, взаимопомощь, использование информации о ребенке для его блага, правила жизни в школе, основанные на признаках толерантности.

Ключевые слова: интерактивное пространство, уклад, уклад школьной жизни, школьный уклад, взаимодействие взрослого и ребенка.
\end{abstract}

Научная специальность: 13.00.00 - педагогические науки. 